\title{
As implicações do estudo da ciência canônica na pastoral
}

\section{The implications of the study of canonical science on pastoral care}

Ao longo da história, a ciência canônica encontrou resistências em círculos intelectuais fora e dentro da Igreja. Correntes de pensamentos protestantes e liberalistas laicistas teceram críticas à concepção do direito canônico como dimensão intrínseca à vida eclesial. Em resposta as essas críticas, a partir do século XVIII, os autores do Ius Publicum Ecclesiasticum, com o objetivo de afirmar a autonomia da Igreja com seus fins e métodos, desenvolveram a noção de "sociedade juridicamente perfeita"

O Concílio Vaticano II promoveu profundas transformações eclesiológicas, ocasionando um processo de superação de muitos dos cânones do Código de 1917. Como resultado desse contexto, houve um movimento antijuridicista que desvalorizava a ciência canônica,

\footnotetext{
${ }^{1}$ Graduado em Psicologia pelo Centro Universitário do Leste de Minas Gerais (2011), graduado em Teologia pela Pontifícia Universidade Católica de Minas Gerais (2018), graduado em Filosofia pela Pontifícia Universidade Católica de Minas Gerais (2019). Atualmente, é mestrando em Direito Canônico pelo Instituto Superior de Direito Canônico Santa Catarina.

${ }^{2}$ GERALDO, Denilson. A eclesialidade e metodologia da ciência canônica. In: REVISTA SCIENTIA CANONICA, v. 2, n.4, 2019, p. 21-51.
} 
identificando-a como ultrapassada. Diante disso, foi necessário aprofundar a reflexão sobre a natureza e a função do direito canônico na vida e na prática eclesial.

João Paulo II considerava o Código de Direito Canônico, de 1983, como "o último documento do Concílio Vaticano II"; um roteiro para a efetivação das deliberações advindas do Concílio. Para Bento XVI, a promulgação do código latino e do código oriental seguiu a hermenêutica da continuidade do Concílio. Visto que o novo Código é considerado como o último documento do Concílio, ele traduz em uma linguagem jurídica as propostas emanadas dos documentos conciliares e terá implicações diretas na vida pastoral.

Diante dos argumentos contrários à juridicidade da Igreja, o Concílio no decreto Optatam Totius afirma que a posição do direito canônico é a de atender ao "mistério da Igreja", ou seja, o direito é constituinte da natureza eclesial; tal afirmação determinará o método científico canônico. Para Bento XVI, são nas verdades de fé que o direito canônico encontra o seu fundamento e o seu sentido; por isso, a lei da ação deve ser expressão da lei da fé.

A Escola de Munique, com Klaus Morsdorf, considerava o direito canônico como uma disciplina teológica com método jurídico. Tal interpretação é limitada, pois o direito canônico possui uma linguagem e um método próprio, diferentemente da metodologia e da linguagem teológicas. Por mais que o direito canônico tenha interferências diretas na vida pastoral da Igreja e estabeleça diálogo com a Teologia, ela é uma ciência com uma epistemologia específica.

Como resposta à visão antijurídica da Igreja, o Código de 1983 foi permeado pelo espírito pastoral do Concílio Vaticano II, ao mesmo tempo em que conservou a estrutura jurídica a serviço da verdade e acessível a todos. Para Francisco, deve haver conexão entre a prática pastoral e o direito canônico; além disso, ele afirma que o direito canônico pertence essencialmente à Igreja; tem um método próprio e destina-se à pastoral. 
A Evangelii Gaudium ${ }^{3}$, primeira Exortação Apostólica do Papa Francisco, insiste na necessidade de a Igreja viver uma conversão pastoral, que implica na mudança das estruturas organizacionais e pastorais. Precisamos ser uma Igreja em saída que vai ao encontro da humanidade em suas periferias existenciais e sociais; que acolhe e cuida dos feridos e anuncia ao mundo a alegria do evangelho. $\mathrm{Na}$ conversão das estruturas pastorais que visam ao bem do Povo de Deus, os serviços relacionados à dimensão jurídica-canônica precisam ser cada vez mais acessíveis aos fiéis, acolhendo-os em suas necessidades; além disso, é necessário que eles tenham conhecimento da legislação da Igreja, de modo que possam gozar dos seus direitos e cumprir os seus deveres.

O direito canônico não é uma disciplina pastoral, mas tem como finalidade o bem do Povo de Deus. Paulo VI, para contrapor interpretações errôneas sobre o Concílio Vaticano II que qualificavam a ciência canônica como "juridicismos", defendia que a dimensão jurídica é constituinte da mesma Igreja. A Exortação "Querida Amazônia" reafirma o direito dos fiéis e comunidades amazônicas terem o acesso à celebração eucarística, fonte e ápice da vida da Igreja, lugar privilegiado na economia da salvação ${ }^{4}$. Por meio do direito canônico com seu método científico jurídico, a Igreja manifesta a justiça na história da humanidade. Garantir aos povos amazônicos o direito ao acesso à celebração eucarística é promover a justiça eclesial.

A normativa atual, para o estudo em direito canônico, prevê que a ciência canônica estabeleça diálogo com a cultura contemporânea para conhecer as suas dores e assim propor soluções. A Constituição Apostólica Veritatis Gaudim definiu que as disciplinas canônicas devem ser desenvolvidas à luz da lei evangélica, em

\footnotetext{
${ }^{3}$ FRANCISCO. Exortação apostólica evangelii gaudium, 24 nov. 2013. In: AAS 27, 2013, p. 1031.

${ }^{4}$ FRANCISCO. Exortação apostólica pós-sinodal "Querida Amazônia". 02 fev. 2020, $\quad$ n. $89 . \quad$ Disponível em: $<$ http://www.vatican.va/content/francesco/pt/apost_exhortations/documents/papafrancesco esortazione-ap_20200202_querida-amazonia.html\# ftnref136>
} 
conexão com os fundamentos teológicos, a fim de formar os alunos para a investigação científica, para o magistério e para assumir os encargos eclesiásticos.

Ao tratar da presença feminina na ação evangelizadora e pastoral na Amazônia, a Exortação Pós-sinodal "Querida Amazônica" reconhece o papel de muitas mulheres na animação das comunidades eclesiais e insiste que elas podem exercer serviços e funções que não requeiram a ordem sacra ${ }^{5}$. O canonista é um jurista que trabalha com uma ciência aplicada às questões concretas. Um Instituto de formação intelectual na área do direito canônico, na região Amazônica, poderia contribuir para a formação qualificada dos agentes de pastoral, religiosos e religiosas, homens e mulheres, que atuam nas várias frentes missionárias, dentre elas da prática da jurídica canônica, dedicando especialmente à pesquisa e reflexão de temas que envolvem a vida eclesial na região amazônica.

A Exortação "Querida Amazônia" insiste na necessidade de a Igreja trilhar novos caminhos de conversão pastoral na região Amazônica, dialogando com os indígenas, jovens, migrantes e habitantes da cidade, como um serviço à vida plena que impele a proclamar Jesus Cristo e a Boa Nova do seu Reino a todos. O fim último do direito canônico é a promoção da justiça e a salvação das almas; por isso, povos amazônicos devem ter seus direitos eclesiais conhecidos e garantidos.

${ }^{5}$ FRANCISCO. Exortação apostólica pós-sinodal "Querida Amazônia". 02 fev. 2020, n.103. 